\title{
REVISION OF THE FAMILY CHLOROPIDAE (DIPTERA) IN IRAQ
}

\author{
Hanaa H. Al-Saffar \\ Iraq Natural History Research Center and Museum, University of Baghdad, \\ Baghdad, Iraq \\ Corresponding author: hanaahani2014@gmail.com
}

Received Date:27 March 2018

Accepted Date:30 April 2018

\begin{abstract}
The aim of this study is to survey and make to revision the genera and species of Chloropidae fauna of Iraq. The investigation showed four species belonging four genera, which belongs to two subfamilies, and one unidentified species belonging to the genus Elachiptera Maquart, The specimens were compared with stored insects at Department of Entomology and invertebrates, Iraq Natural History Research Center and Museum.
\end{abstract}

Key words: Brachycera, Chloropidae, Diptera, Eye fly, Grass fly, Iraq.

\section{INTRODUCTION}

The family Chloropidae Schoenher,1840 (frit flies, grass flies or eye flies) belongs to super family Carnoidea. It has four subfamilies: Chloropinae, Oscinellinae, Rhodesiellinae, and Siphonellpsinae (Brues et al.,1954).

The members of Chloropidae are worldwide distribution or cosmopolitan and are found in all Zoogeographical regions except Antarctica; they are about 3000 described species under 200 genera (Sabrosky,1989; Canzoneri, et al., 1995; Nartshuk, 2012; Bazyar et al., 2015).

The grass flies are also found in marshes, vegetation areas, forests; the members of the family are phytophagous. Some species as a gall maker of stems likes Lipara lucens Meigen, 1830 on Phragmites australis (Poaceae) are affected on the morphological tissue (Van de Vyvere and De Bruyn, 1988); and many larvae feed and developed flower heads, shoots and seeds of Poaceae and some feed on the stems of cereals, thus affected of economic production (Alford,1999; Karpa, 2001;Petrova et al., 2013). On the other hand some species as saprophytic which feed on damaged plant tissue by other insects such as Atherigona spp. (Diptera, Muscidae), larvae of lepidopterus stem borer and other arthropods (Von Tschirnhaus, 2002); and as predators of several insects like: aphids, eggs of grasshoppers and nuisance spiders, oothecae of mantids and eggs of Hemiptera (Dawah and Abdullh, 2006).

Some species have medical and veterinary importance( Nikapy et al.,2013) such as eye gnats attracted to human and other mammals where they hover about the face, body orifices and open wounds, such as Liohippelates spp. and so that take part of a mechanical transition of several organisms which cause diseases to humans and livestock animals in North and South America (Bram et al., 2002; Hall and Gerhardt, 2009). 


\section{Revision of the family Chloropidae}

The oriental eye fly Siphunculina funicola Meijere, 1905 is a nuisance to humans and domestic animals which feed on various secretions including eye secretions, mucus membrane, and other moist surfaces of their hosts and carry and transmit fatal pathogens like fungi, viruses and bacteria to humans and other hosts. The eye flies are found aggregating on many hanging substrates like strings, electrical lines and wires, ropes, nest trailing, decorators, cobwebs, clothes hangers, cotton threats which as their medical and forensic importance (Sathe et al., 2014); also there are some chloropid flies as parasites of amphibians (frogs) Crinia signifera by Batrachomyia sp. (Lemckert, 2000).

The adult of Chloropidae diagnosis by many features such as: small 1-5 $\mathrm{mm}$ rarely eight millimeters in length, variable in colors (black, blackish-grayish and bright yellow and black with vittae; head is somewhat angular; ocellar triangular large and conspicuous, shining, postvertical bristles converging, parallel or absent; vibrissae reduced or absent; antennae project and prominent with arista located at basal, dorsal and scarcely terminal, bare, plumose or pubescent. Subcostal vein incomplete, costa broken at near the end of first radial vein (R1); second discal cell and basal cell are united, vein Cula slightly sinuate and anal cell wanting. The previous are characters accepted by the authors: Essig (1947), Comstock (1948), Mc Alpine(1958), Curran (1965), Cole (1969), Borror and White (1970), Oldroyd (1970), Unwin (1981), Scudder and Cannings (2006).

\section{MATERIALS AND METHODS}

Many specimens of grass flies were collected by sweeping net in various habitats from several regions of Iraq during 2017. Then the flies were killed by freezing for 24 hours; the specimens mounted with insect pins and kept in insect collection boxes till diagnosed.

To identify the genera, by using several taxonomic keys such as: Curran (1965), Cherian (2002), An and Yang (2005), Nartshuk and Fedoseeva (2011), Deeming and Al-Dhafer (2012), Khaghaninia and Khameneh (2015) and Khameneh et al. (2016).

The specimens were compared with previously identified specimens which had been diagnosed and stored at Department of Entomology and Invertebrates, Iraq Natural History Research Center and Museum, University of Baghdad.

\section{RESULTS AND DISCUSSION}

In this study the survey showed four species, four genera and one unidentified species that belong to the genus Elachiptera Macquart belonging to two subfamilies Chloropinae and Oscinellinae. The key to identify of subfamilies and genera was constructed, the global distribution of each species was shown in this investigation.

Key to subfamilies and genera of Chloropidae in this study :

1- Costa ending between the apices of $\mathrm{R} 4+5$ and $\mathrm{M} 1+2$; vertical bristles weak or absent. Subfamily: Chloropinae 2

- Costa extending to apex of M1+2; vertical bristles well developed, the inner weaker than the outer....... Subfamily : Oscinellinae

2- Hind femora greatly thickened and tibiae strongly arcuate

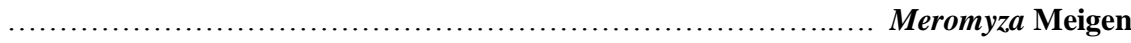

- Hind femora not thickened and hind tibiae almost or quite
straight. Thaumatomy Zenker 
3- Body shining black; mesonotum with normal shape and depression at the end; all femora black. Oscinella Becker

- Body dull black ,yellowish -brownish; mesonotum with dark vittae or spots, femora yellow - brownish Elachiptera Macquart

Family, Chloropidae Schoenher, 1840

Synonyms: Chloropidae, Rondani, 1856

Oscinidae Fallen, 1820

Mindidae, Paramonov, 1957

Echiniidae, Paramanov, 1961

Siphonellopsidae,Nartshuk, 1987

\section{Subfamily: Chloropinae Rondani, 1856}

Genus: Meromyza Meigen, 1830

Type species: Musca saltarix Linnaeus, 1761

Diagnostic characters: Body is elongated, yellowish and greenish in color; head is square shaped with tiny setae; ocellar triangle with black spots; the length of flagellum little longer of broad, mesonotum has black, brownish longitudinal or yellow vittae; veins $\mathrm{R} 2+3$ and $\mathrm{R} 4+5$ much bent forward.

Meromyza nigriventris Maqurt, 1835

Materials Examined: $(5 \circ+, 4 \hat{\jmath})$ : Baghdad, Bab Al -Mudham, $19,1 \hat{\jmath}$ from weeds at 3.xi.2017; Basra, Abu- Al Khaseeb, $39+, \oint^{\Uparrow}$ from alfalfa field at 21.III.2017; Karbala- AlHussaynia, 1 , $2 \hat{\sigma}^{\hat{\sigma}} \mathrm{d}$ from grass at 4.V.2017.

Description: The body is elongated, black -brownish color, mesonotum black with two parallel yellow vittae.

Global Distribution: Iraq (El- Haidary et al., 1974); Japan (Kanmiya, 1978); Palearctic region (Nartshuk, 1984); Arabian Peninsula (Deeming and Al-Dhafer, 2012); China ( An and Yang, 2005); Romani (Pirvu, 2005); Mediterranean islands (Nartshuk, 2013); Finland (Nartshuk and Kahanpää,2014); Iran (Rabeih et al., 2012; Khameneh and Khaghaninia, 2016); Uzbekistan (Khamraev and Davenport, 2004); Poland (Bereś, 2015) and Turkey (Kubík and Barták, 2017).

Genus : Thaumatomyia Zenker, 1833

Synonyms: Chloropisca Loew ,1866 Pseudochlorops Malloch, 1914

Type species: Thaumatomyia prodigiosa Zenker, 1833 = Chlorops notata Meigen, 1830

Diagnostic characters: body elongated and flattened in both sexes, scutellum flattened on disc, with distinct marginal rim , apical secutellar bristles closely approximated.

Thaumatomyia sulcifrons Becker, 1907

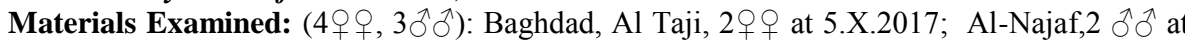
10XI.2017; Wasit, Al Aziziyah, 2 ${ }^{\circ},{ }^{7}$ at 5.V.2016.

Description: small flies 4-5mm. yellowish brown in color; head semispherical, arista long, oceller triangle large with small dull spot; mesonotum with three rimbs, the middle one reaching the interior margin of thorax; scutellum brighting yellow.

Global Distribution: In Iraq (Khalaf, 1963); Arabian Peninsula (Deeming and Al-Dhafer, 2012); Mediterranean islands (Nartshuk, 2013) and Iran (Bazyar et al., 2015 ). 


\section{Thaumatomyia sp.}

Global Distribution: Iraq (El-Haidary et al.,1974).

2-Subfamily: Oscinellinae Becker, 1910

Genus: Oscinella Beker,1909

Type species: Oscinella frit, Linnaeus, 1758

Diagnostic characters: First basal cell scarcely wider at middle than end.

Oscinella frit (Linnaeus, 1758)

Synonyms: Musca frit L. 1758

Oscinella exigua Collin, 1964

Oscinella granaria (Curits, 1846)

Chlorops aenea, Roser, 1840

Hydrellia rufitarsis, Meigen, 1838

Materials Examined: $\left(6+q, 2 \delta^{\top}\right)$ : Baghdad, Jaddria $3 q q$ at 25.III.2017; Al- Ttaji. $2 \widehat{\jmath}, 10 . I V .2017$; Karbala, 3 우 at 20.V.2017.

Description: small black fly, legs dull black, tibiae never entirely yellow.

Global Distribution: In Iraq (Hussain,1963); Europe, Latvia (Karpa, 200; Petrova et al.,2013); Arabian Peninsula (Deeming and Al-Dhafer, 2012); Spain (Nartshuk et al., 2013); Turkey, Iran, Europe, U.S.S.R. (Gentry, 1965); Mediterranean islands (Nartshuk, 2013); Iran (Bazyar et al., 2015).

Genus: Sabroskyina Beschovski, 1987

Type species: Lioscinella mimica Collin, 1949.

Diagnostic characters: First basal cell of wing is very much broadened at mid -length.

Sabroskyina aharonii (Duda,1933)

Synonyms: Oscinella aharonii Duda, 1933 (Sabrosky 1963)

Global Distribution: Iraq (Deeming and Al-Dhafer, 2012); Arabian Peninsula (Deeming and Al-Dhafer, 2012); Turkey (Kubík and Barták, 2017) .

Genus: Elachiptera Maquart,1835

Synonyms: Ceratobarys Coquillett, 1898

Type species: Chlorops brevipennis Meigen

Diagnostic characters: Third antennal segment haired; Scutellum with dorsal surface flat, or trapezoid, the marginal setae arising from more or less distinct tubercles.

\section{Elachiptera sp.}

Global Distribution: Iraq (Khalaf and Al-Omar,1974).

\section{LITERATURE CITED}

Alford, D. V. 1999. A text book of agricultural Entomology. Blakwell Science, 314pp.

An, Sh. and Yang, D. 2005. Review of the genus Meromyza from China (Diptera: Chloropidae). Entomologica Fennica, 16: 151-158.

Bazyar, Z., Dousti, A. F., Von Tschirnhaus, M. and Fallahzadeh, M. 2015. A first overview of the fauna of Chloropidae of Iran (Diptera, Acalyptratae). Turkish Journal of Zoology, 39: 1041-1049. 


\section{Hanaa H. Al-Saffar}

Bereś, K. 2015. The occurrence and harmfulness of Oscinella frit L. (Diptera: Chloropidae) to maize cultivars cultivated for grain in South-Eastern Poland. Acta Scientiarum Polonorum seria Agricultura, 14(3): 15-24.

Borror, D. J. and White, R. E. 1970. A field guide to the insects of North Mexico. Houghton Mifflin Company Boston, xi + 404pp.

Bram, R. A., George, J. E., Reichard, R. E. and Tabachnick, W. J. 2002. Threat of foreign arthropod-borne pathogens to livestock in the United States. Journal of Medical Entomology, 39(3): 405-416.

Brues, C. T., Melander, A. L. and Carpenter, F. M. 1954. Classification of insects, key to the living and extint families of other terrestrial arthropods. Bulletin of Museum and Comparative Zoology at Harvard Collage, vol.108, Cambridge Mass., U.S.A. printed for the museum, 917pp.

Canzoneri, S. K., Gordoncov, N. P., Karivosheina, L. Minari, E. Nartshuki, E., Papp, A. R. and Rivosecch, I. 1995. Diptera Opomyzoidea, Carnoidea, Spheroceroidea, 1-27. In: MINELLI A., RUFFO S., LA POSTA S. (eds.), 1993-1995 - Checklist delle specie della fauna italiana. Fascicoli 1-110. Edizioni Calderini, Bologna.

Cherian, P. T. 2002. The fauna of India and adjacent countries Diptera: Chloropidae, Siphonellospinae and Rhodesiellinae. Zoological Survey of India, Vol. IX Part I, 368pp.

Cole, F. R. 1969. The flies of Western North America. University of California Press Berkeley and Los Angeles, 693 pp.

Comstock, J. H. 1948. An introduction to Entomology. Ninth Edition Revised. Ithaca, New York Comstock Publishing Company Inc, 1064 pp.

Curran, C. H. 1965. The families and genera of North American Diptera. $2^{\text {nd }}$ rev. ed. Henry Trip, $515 \mathrm{pp}$.

Dawah, H. A. and Abdullah, M. A.2006. New records of Chloropidae (Diptera) from Southwest Saudi Arabia with some biological information, World-wide geographical distribution and taxonomic feature. Saudi Journal of Biological Sciences, 13 (1): 24-34.

Deeming, J. C. and Al-Dhafer, H. M. 2012. Chloropidae from the Arabian Peninsula (Diptera: Cyclorrhapha). Zoology in the Middle East, 58: 3-86

El-Haidary, H., Fattah, Y. M. and Sultan, J. A. 1974. Contribution to the insect fauna of Iraq. Ministry of Agriculture and Agrarian Reform, Directorate General of Plant Protection, Part 5, Bulletin, No. 212, 12pp.

Essig, E. O. 1947. Collage Entomology. New York the MacMillan Book Company.900 pp. (Order: Diptera, Chapter 35: 728 -818). 


\section{Revision of the family Chloropidae}

Hall, R. D. and Gerhardt, R. 2009. Flies (Diptera), Chapter 10: 137-152 . In: Mullen, G. R. and Durden, L. A. Medical and Veterinary Entomology. Second Edition, Academic Press is an imprint of Elsevier, Xvii $+637 \mathrm{pp}$.

Hussain, A. A. 1963. Provisional list of insects pests and bibliography of insect fauna of Iraq. Bulletin of College Science, University of Baghdad, 7: 43-83.

Gentry, J. W. 1965. Crop insects of Northeast Africa-Southwest Asia. Agricultur handbook No. 273, Agricultural Research Service, United States Department of Agriculture, $214 \mathrm{pp}$.

Kanmiya, K. 1978. Revision of the genus Meromyza Meigen (Diptera: Chloropidae) in Japan, with three newly recorded species. Applied Entomology and Zoology, 13(14): 231242 .

Karpa, A. 2001. Revision of Chloropidae of the collection of B. A. Gimmerthal and a checklist of Latvian Chloropidae (Diptera). Latvijas Entomologs, 38: 21-26.

Khaghaninia, S. and Khameneh, R. N. 2015. Some of the grass flies (Diptera, Chloropidae) fauna of West Azarbaijan province - Iran. Linzer Biologische Beiträge, 47(2): 1573-1579.

Khalaf, A. N. and Al-Omar, M. A. 1974. A second list of insects from Iraq. Biological Research Center, Publication, No. 2, 41pp.

Khalaf, K. T. 1963. Faunistic notes in Iraq. Bulletin of the Iraq Natural Histore Museum, 2(8):1- 12.

Khamraev, A. Sh. and Davenport, C. F. 2004. Identification and control of agricultural plant pests and diseases in Khorezm and the Republic of Karakalpakstan, Uzbekistan. ZEF Work Papers for Sustainable Development in Central Asia, No. 8, 132pp.

Khameneh, R. A. and Khaghaninia, S. 2016. Fauna of grass flies of the subfamily Chloropinae (Diptera: Chloropidae) in Shabestar region with three new records for Iran. Journal of Insect Biodiversity and Systematics, 1(2): 101-110

Khameneh, R. A., Khaghaninia, S. and Kubik, S. 2016. Taxonomic study of the genus Meromyza Meigen, 1830 (Diptera: Chloropidae) in Shabestar region with two species as new records for the Iranian fauna. Biharean Biologist, 10 (2): 74-78

Kubík, Š. and Barták, M. 2017. Frit flies of Turkey with descriptions of two new species and new records (Diptera, Chloropidae). ZooKeys, 667: 131-154 .

Lemckert, F. 2000. Parasitism of the common eastern froglet Crinia signifera by flies of the genus Batrachomyia (Diptera: Chloropidae): Parasitism rates and the influence on frog condition. Australia zoologist, 31(3): 492-495.

McAlpine, D. K. 1958. A key to the Australian families of Acalptrate Diptera (Insecta). Records of the Australian Museum, 24(12): 183-190. 
Hanaa H. Al-Saffar

Nartshuk, E. P. 1984. Family Chloropidae. In: Soós, Á. and Papp, L. (eds.),Catalogue of Palaearctic Diptera 10:Clusiidae- Chloropidae; 222-299. Budapest Akademiai Kiado, 402 pp.

Nartshuk, E. P. 2012. A check list of the world genera of the family Chloropidae (Diptera, Cyclorrhapha, Muscomorpha). Zootaxa, 3267: 1- 43.

Nartshuk, E. P. 2013. Grass flies of the family Chloropidae (Diptera) on Mediterranean islands. Zoosystematica Rossica, 22(1): 129-140.

Nartshuka, E. P. and Fedoseeva, L. I. 2011. A review of the grass flies of the Genus Meromyza Meigen, 1830 (Diptera, Chloropidae) of the Palaearctic fauna, with a key to the species, analysis of synonymy, host Specialization, and geographical distribution: Part 1 .Entomological Review, 91(1): 103-120

Nartshuk, E. P. and Kahanpää, J. 2014. Checklist of the family Chloropidae (Diptera) of Finland. ZooKeys, 441: 311-318.

Nartshuk, E. P., Martín, B. D. Marta, I. and Bordas, S. 2013. New Chloropidae from the Basque Country (northern Spain). Additions to the Chloropidae (Diptera) fauna from northern Spain, with new records. Boletin de la Asociation Espaňola De Entomologia, 37 (3-4): 173-179.

Nikpay, A., Nartshuk, E. P. and Goebel, F. R. 2017. New record of species complex of Chloropidae (Insecta: Diptera) from sugarcane fields in Iran. Entomologie Faunistique - Faunistic Entomology, 70:89-94.

Oldroyd, H. 1970. Diptera, Introduction and key to the families. Handbook for identification of British Insects, Royal Entomological Society of London, (1) 104 pp.

Petrova, V., Jankevica, L. and Samsone, I. 2013. Species of phytophagous insects associated with strawberries in Latvia. Proceedings of the Latvian Academy of Sciences. Section B, 67. (2): 124-129.

Pirvu, C. 2005. Diptera from the green corridor of the Danube (Romania). Travaux $d u$ Muséum National d'Histoire Naturelle «Grigore Antipa», 68:147-176.

Rabieh, M. M., Alikhani, M., Arkani, T., Taji, M. and Nartshuk, E. P. 2012. Checklist of grass flies (Diptera: Chloropidae) of Markazi province, Iran. An International Journal of Dipterological Research, 23(2): 95-101.

Sabrosky, C. W. 1989. Chloropidae. In: Evenhuis N. L. (ed.), Catalogue of the Diptera of the Australasian and Oceanian Regions. Bishop Museum (Natural History), 1437 pp.

Sathe, T. V., Kamble, C. and Jadav, D. 2014. Laboratory Diet for Adult Eye Fly Siphunculinaue funicola (Diptera: Chloropidae), A Forensic and Medical Pest. International Journal of Chemical, Environmental and Pharmaceutical Research, 5(1) 19-22.

Scudder, G. G. E. and Cannings, R. A. 2006. The Diptera families of British Colombia. The Diptera families of British Colombia, 158pp. 


\section{Revision of the family Chloropidae}

Unwin, D. M. 1981. A key to the families of British Diptera. Field studies, 5: 513 - 553.

Van de Vyvere, I. and De Bruyn, L. 1988. Morphological and histochemical analysis of galls of Lipara lucens (Diptera, Chloropidae) on Phragmites australis (Poaceae). Canadian Journal of Botany, 76: 1374-1384.

Von Tschirnhaus, M. 2002. Feeding habitat and so-called phytophagy of Chloropidae (Diptera), p. 245. In: Fifth International Congress of Dipteriology, Abstract volumes, University of Brisbane, Australia, xxv $+296 \mathrm{pp}$. 
Bull. Iraq nat. Hist. Mus.

December, (2018) 15 (2): 113-121

$$
\text { مر اجعة لعائلة ثنائية الاجنحة (Chloropidae) في العراق }
$$

$$
\text { مركز بحوث و متحف التاريخ الطبيعي / جامعة بغداد، بغداد، العر اق الصار }
$$

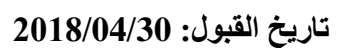

$$
\text { تاريخ الاستلام: 2018/03/27 - ت 20 }
$$

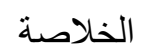

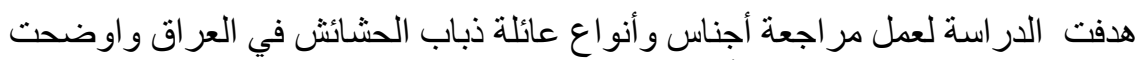

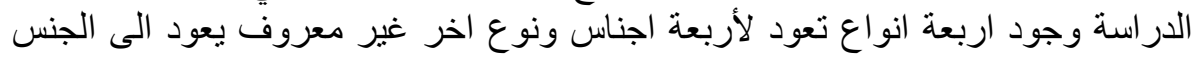
Elachiptera Maquarta

قورنت العينات مع النماذج الحشرية المحفوظة في فسم الحشر ات و اللافقريات/ مركز

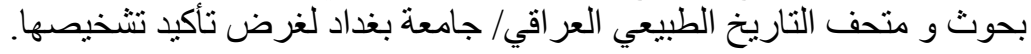

